\title{
Pathways for Participatory Water
} Governance in Ashaiman, Ghana: Learning from Institutional Bricolage and Hydrosocial Perspectives

\section{MEGAN M. PELOSO \\ Corresponding Author: mmpeloso@gmail.com}

\section{LEILA M. HARRIS}

University of British Columbia, 2017

Final version: Megan M. Peloso \& Leila M. Harris (2017) Pathways for Participatory Water Governance in Ashaiman, Ghana: Learning from Institutional Bricolage and Hydrosocial Perspectives, Society \& Natural Resources, 30:12, 1491-1506, DOI: 10.1080/08941920.2017.1364451

Citations of this work should use the final version as noted above 


\section{TABLE OF CONTENTS}

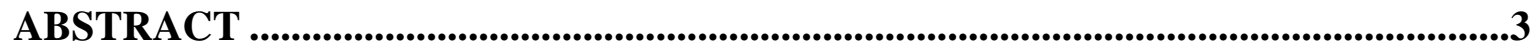

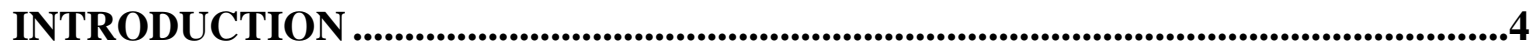

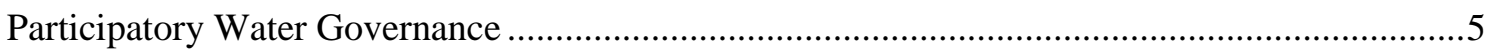

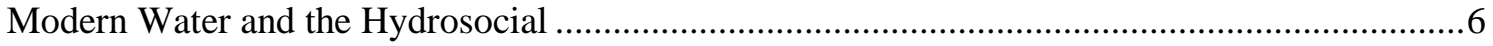

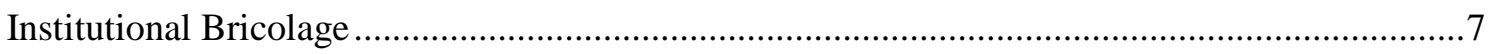

Water Access in Ashaiman, and Greater Accra ............................................................

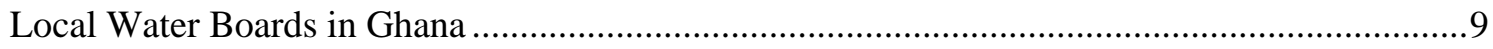

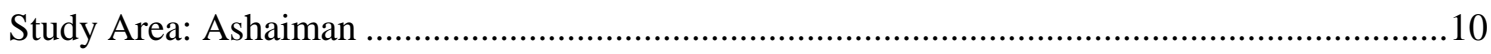

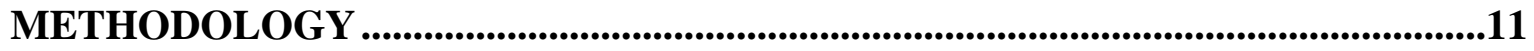

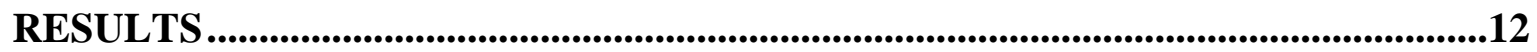

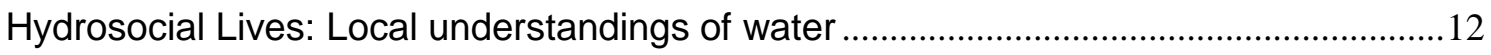

Participatory Water Governance: Pathways and possibilities .................................................15

Bricolage: Building on a foundation of existing norms and networks ...................................17

DISCUSSION_.............................................................................................................19

Revisiting governance histories and possibilities...................................................................

Implications for participatory water governance and policy recommendations........................21

CONCLUSION

ACKNOWLEDGEMENTS .....................................................................................................24

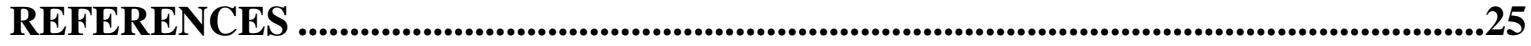




\section{ABSTRACT}

Coupling a hydrosocial perspective with institutional bricolage, this research considers possibilities for participatory water governance in Ashaiman, a peri-urban settlement of Accra, Ghana. We explore three questions: (1) How do people in Ashaiman evoke ideas or experiences of water in general and water governance in particular? (2) What possibilities currently exist for engaging the community in key water-related decisions? (3) What possibilities exist for enhanced participatory water governance in this context, including potential for and interest in new institutions and engagement processes? Results of qualitative interviews and semistructured observation suggest that a siloed, water-centric approach inadequately captures everyday realities of water as hydrosocial and of existing institutions in Ashaiman. In contrast to "modern water," we propose that water issues may be more meaningfully addressed as bundled with social welfare. Potential implications and alternative ways of understanding socio-institutional arrangements for participatory water governance are explored.

KEYWORDS: Institutional analysis, participatory governance, social dimensions of natural resource management, water, West Africa 


\section{INTRODUCTION}

Coupling a hydrosocial perspective with an institutional bricolage approach, this research considers participatory water governance in the context of Ashaiman, a peri-urban settlement on the outskirts of Accra, Ghana's capital city. As the settlement continues to grow, difficulties remain regarding water supply, access, and affordability. We consider what possibilities and pathways do exist at present, and might be possible in the future, for participatory water governance in this context, particularly in ways that might help to alleviate these concerns.

Local water boards (LWBs), water user associations (WUAs), and similar institutions have been highlighted in the literature as a key mechanism to improve water access and quality in underserved areas, and to bring marginalized communities more meaningfully into decision-making processes. In other neighborhoods of metropolitan Accra, LWBs have been established to promote community participation in water management. However, the advantages, limitations, and potential of LWBs and other participatory water governance mechanisms remain valuable questions for consideration.

In this article, we investigate possibilities and pathways for participatory water governance in Ashaiman, exploring three related questions: (1) How do people in Ashaiman evoke ideas or experiences of water in general, and water governance in particular? (2) What institutions exist for engaging the community in key decisions related to water and its management? (3) What possibilities exist for participatory water governance in this context, including potential for and interest in new institutions and engagement processes? Engaging this final question of how participatory water governance may manifest in ways that are attentive to local context, our approach is informed by conceptual debates related to modern water, the hydrosocial, and institutional bricolage — concepts reviewed below to lay the theoretical foundations for the paper. 


\section{Participatory Water Governance}

Our analysis adds to literature on participatory water governance, including critical assessments of its putative benefits. We understand participatory water governance to include opportunities for communities to engage in water-related decisions that affect them. Water governance, more broadly, refers to the practices and politics through which decisions are made about water's use and management, including the degree to which communities can provide input, and what types of guiding assumptions or frameworks inform how water is used, or managed (Rogers and Hall 2003).

While it is commonplace to promote participatory water governance as essential to effective or equitable water access and decision-making (indeed hegemonic, Harris et al. 2013), there are also significant challenges to these notions. Among them, it has been noted that participatory processes may further entrench key inequities, particularly when practices and institutions do not explicitly challenge marginalization (Morales and Harris 2014; Cooke and Kothari 2001). Crafting institutions without consideration of local context can also lead to the creation of participatory spaces that are ineffective, exclusive, or lacking in meaning (Cornwall 2002), at times establishing "paper organizations" (Bruns 2013, p.263), where layers of formal reporting and procedures supplant pre-existing practices that may indeed have been robust and effective. Formalized institutions have also been resisted or resented by the communities they are intended to serve. For example, Vavrus (2003) explains how water user groups were viewed by residents in rural Tanzania as 'phonies', lacking credibility based on incongruity with established social practices.

It is not the focus of this paper to evaluate the merits of participation or its different forms, nor to evaluate whether or not specific modes of participation are substantive or equitable. Instead, our aim is to learn from the broader debates on participation, and the broader literature on participatory water governance, to answer the research questions outlined above. It is also worth noting that in contexts such as Ashaiman where water is insecure, residents must engage in "multiple, repetitive" actions to gain access to affordable and safe water (Peloso and Morinville 2014). Recognition of this reality must also be central when we consider possibilities for participatory water governance. 


\section{Modern Water and the Hydrosocial}

As suggested by the broad definition of water governance, how water is viewed affects a range of considerations involved in its use and management. Fundamentally, as Linton (2010) writes, "water is what we make of it." Both historically and in the present, certain paradigms and narratives have dominated water management, including those associated with the hydraulic mission (Gleick 2000). Linton (2010) has compellingly argued that our dominant view today is one of 'modern' or 'abstract' water, a hegemonic paradigm that considers water as a discrete resource distinct from social processes and consequences (ibid; 2014).

One appeal of 'modern' water relates to its legibility, providing a sense of the ability to control the hydrologic cycle (cf. Scott 1998) so that it appears cleansed of social and political relations that complicate its use and management. In contemporary urban spaces, water is often accessed and experienced in ways consistent with abstraction. For instance, hidden infrastructure, such as metering or subterranean infrastructure, create relationships with water that are technologically and bureaucratically mediated (e.g. turning on the tap while not knowing what the source of the water might be). These relationships serve to further separate or "un-bundle" hydrological processes from social and political processes (Brooks et al. 2009). As described by Kaika and Swyngedouw 2000, p. 120):

"Burying the flow of water via subterranean and often distant pinpointed technological mediations (dams, purification plants, pumping stations) facilitates and contributes to masking the social relations through which the metabolic circulation of water takes place."

These separations have myriad implications for social interactions, for uses and conditions of water, and for urban infrastructures. Among them, hydrological abstraction can produce highly unequal access to water while at once being lauded as a symbol of progress (Kaika and Swynedouw 2000). Others have highlighted the ways that separations of water from societal relations have served campaigns to promote the commodification of water (Budds 
and Hinojosa 2012; Linton 2010), or to generally promote a sense that water can be reasonably managed by market systems and technological infrastructures, rather than being considered through lenses of justice, equity or ethics (Joy et al. 2014; Perreault 2014).

To counter the tendency to abstract or unbundle water from its social context, there is growing focus on concepts including the hydrosocial, hybrid water, and waterscapes - all terms employed to signal the importance of water as socially and politically embedded (cf. Perreault 2014; Linton 2014; Budds and Hinojosa 2012). Our examination builds on the hydrosocial concept by engaging with core understandings of what water is, and how it is embedded in contextually specific meanings and socio-institutional fabrics. With particular attention to perspectives offered by interviewees in the context of peri-urban Ashaiman, we argue that these concepts are useful to inform our assessment of what participatory water governance could and should be, for this context and elsewhere.

\section{Institutional Bricolage}

A final concept that is useful for our approach to the research questions is institutional bricolage'. Drawing from the earlier works of Claude Levi-Strauss and Mary Douglas, Frances Cleaver (2002, p. 16) uses the term to point out the limitations of overlymanagerial or functionalist approaches in institutional theory, describing rather that in many cases "mechanisms for resource management and collective action are borrowed or constructed from existing institutions, styles of thinking and sanctioned social relationships." Bricolage is thus allied with critical or post-institutionalist perspectives (Ostrom 1990; Mehta et al. 1999), that recognize institutions "not just as formalized, visible entities but also as manifestations of negotiated social practices" (Cleaver and Toner 2006, p. 209).

Institutional bricolage, in particular, focuses on flexible, adaptive arrangements that can address changing needs while maintaining a sense of social grounding and cultural familiarity. This, in turn, lends legitimacy to institutions and may be a key factor in 
creating meaningful and lasting participatory spaces. Together with a hydrosocial perspective, the ideas borrowed from institutional bricolage invite reconsideration of participatory water governance possibilities. This research uses them in concert to draw attention to local, endemic, or informal approaches that might be adapted to deal with water related concerns. Employing a post-institutionalist lens, our analysis is concerned with the informal approaches that might be more effective, flexible, adaptive, multipurpose, or equitable than the types of formal institutions that are often promoted in water governance policy circles (cf. Ostrom 1990).

To be clear, this research does not evaluate various institutions for water management, nor it is our intention to over-romanticize traditional governance; it is well known that communities are not homogenous and are often characterized by considerable inequities (Agrawal and Gibson 1999; Cooke and Kothari 2001). However, learning from institutional bricolage and allied concepts, we work towards opening up an analysis with particular interest in identifying pathways and opportunities that do not undermine or risk uprooting existing informal social networks, norms, and institutions (ibid).

\section{Water Access in Ashaiman, and Greater Accra}

Water access in Ashaiman, and peri-urban Ghana more generally, is uneven, erratic and an ongoing challenge given issues of inadequate infrastructure, rapid migration to urban centers, insufficient financial resources, and related concerns (Adank et al. 2011). While water is not biophysically scarce in Ghana; many urban and rural areas experience conditions of 'manufactured scarcity' (Mehta 2005)—where lack of water results from a myriad of technical, financial, political or social factors that restrict access, quality or distribution. At the time of initial fieldwork (2012), the Ghana Water Company Limited (GWCL, the entity mandated with urban water provision across the country) had long 
relied on a city-wide rationing schedule to deal with ongoing deficits. ${ }^{1}$ The result was that even areas served by the municipal network received water only erratically (Ainuson 2009; Peloso and Morinville 2014), flowing only one or two days per week in some areas. When water is unavailable, middle- and higher-income groups are generally able to cope by purchasing sachet or bottled water for drinking purposes, and by storing water in large propylene containers for later use. Lower income communities may be unable to afford storage infrastructure, resulting in heavy reliance on water vendors, most often purchasing water on a per-bucket basis several times per day (Songsore 2008; Ainuson 2009; Adank et al. 2011; Dapaah and Harris 2017).

\section{Local Water Boards in Ghana}

The first Local Water Board (LWB) in urban Ghana was established by the GWCL in 2007 in the indigenous community of Teshie. Numerous other LWBs have since been implemented across Accra, involving the GWCL, various NGOs, and/or external funders (Morinville and Harris 2014). Generally speaking, LWBs are set up to promote local participation and administer water and sanitation in the community. In their work, Morinville and Harris (2014) explore the promotion and uptake of LWBs across urban Accra, highlighting limitations as well as possibilities for these institutions in terms of improving water access as well as fostering more inclusive water governance. The authors found that LWBs can help raise awareness of important issues, and can facilitate the extension of private connections to the municipal water network. On the other hand, LWBs operate with minimal funding and require volunteer labor inputs, with board members receiving little to no compensation for their involvement (ibid). Moreover, all of the LWBs studied were established by external agencies and not by the communities themselves. Given this, the authors questioned whether the LWBs should be considered

\footnotetext{
${ }^{1}$ Supply networks are now changing due to the implementation of a new desalination plant (Author interviews, 2015).
} 
meaningful sites of participation, and suggested that forms of informal engagement happening outside of this model should be recognized as potentially important in this context.

\section{Study Area: Ashaiman}

Located northeast of Accra, Ashaiman originally developed as a temporary settlement to accommodate workers employed in adjacent Tema, a major industrial hub of Ghana (Owusu 1999). With rapid growth along the Accra-Tema motorway, Ashaiman gained municipal status in 2008, making it the newest of ten municipal districts in the Greater Accra Metropolitan Area (GAMA). With the earliest available statistics estimating only 185 residents lived in Ashaiman in 1952 (Peil 1976), the population size of the settlement has ballooned, rising to approximately 190,972 in 2010 (Ghana Statistical Service 2012). At its height, population growth in Ashaiman reached an annual rate of $4.6 \%$, classifying it as among the fastest growing cities of Ghana (Ainuson 2009, p. 161). The state of infrastructure and access to basic services in Ashaiman varies, but generally can be described as inadequate, with dense living conditions and little by way of formal infrastructure (e.g. roadways, sanitation, or water works). These challenges persist as residents continue to migrate from rural areas and neighboring countries to Ghana's capital in search of employment (Ainuson 2009).

An initial survey conducted in 2012 as part of the larger research effort suggested that no water governance institutions existed in Ashaiman. There was also little understanding among residents regarding who they should speak to, or where they could go, if they had a water related concern (EDGES and AOW 2012). ${ }^{2}$ Since this settlement appeared to be historically marginalized with respect to service provision and water governance

\footnotetext{
${ }^{2}$ Results clearly suggested that no groups were meeting to discuss water explicitly; and the entire sample size in Ashaiman $(n=123)$ responded negatively to the question "Are there NGOs that deal with water issues in your area?"
} 
institutions, a qualitative study of the area offered an opportunity to assess the potential to enhance participatory water governance, as well as serving to better understand constraints that might affect the potential to establish an LWB or similar entity.

\section{METHODOLOGY}

Data is drawn from in-depth, semi-structured interviews and observation conducted during two months of fieldwork in Ashaiman and the GAMA region between May and July 2012 (follow up interviews were also conducted as late as 2015). Selection for individual interviews (total sample $\mathrm{n}=40$ ) was conducted using snowball sampling techniques that included residents and opinion leaders of Ashaiman (75\%), NGO representatives (12.5\%), public utility representatives (7.5\%) and development consultants (5\%). A research assistant, who spoke fluent English as well as Twi and Ga-Dangme, transcribed all interviews. Transcripts were then coded by reviewing and analyzing for key patterns, themes, and discrepancies. Both inductive and deductive methods were incorporated to capture new and divergent concepts and explanations that emerged from open-ended questions (Ryan and Bernard 2003). Observational techniques were particularly important for investigating the context of social organization and local institutions in Ashaiman, particularly as "institutional interaction" cannot be fully captured by individual interviews alone (Denzin and Lincoln 2011, p.535). Field notes were used to document observations, serving as a basis for further questions that were asked in individual interviews. As noted, a survey conducted prior to this research effort established some of the context of water governance and access in the Accra region more generally, and included responses from Ashaiman. $^{3}$

${ }^{3}$ More information on the broader project, including basic survey data and the survey instrument, is available at www.edges.ubc.ca. 
A major focus of the interviews and field-work was to consider the potential for formal participatory water governance mechanisms in Ashaiman, as a survey reported no active water governance institutions. We also queried residents about their general senses of water and daily water challenges, and asked directly what community members saw as the potential for enhanced engagement, or improved management - the focus of our results below.

\section{RESULTS}

Through individual interviews, we looked for common patterns and divergent themes related to participatory water governance. Observations were structured to fill gaps in information about how groups organize and what concerns are often prioritized by individual actors or social institutions. We proceed by first highlighting broad senses of water captured in interviews (Section 4.1). We then consider the appetite for, and appropriateness of, water user groups or local water boards to serve participatory water governance goals (Section 4.2). Finally, engaging insights from an institutional bricolage approach, we analyze existing social norms and networks as potential building blocks of participatory institutions (Section 4.3). We connect these results to an evaluation of possibilities for participatory water governance in the discussion section.

\section{Hydrosocial Lives: Local understandings of water}

"If we have water, we are free." (Interview, 29 June 2012)

One of the crosscutting themes that emerged through interviews related to ways that the status of water sources and local water bodies was linked to views of the self, the community and associated socio-political concerns. Water was also expressed as 
connected to livelihoods, to upward social mobility, as well as notions of urbanity and freedom.

For many, water delivery and consumption infrastructures represented unequal access to an urban lifestyle that is often sought by those who move to informal neighborhoods in peri-urban spaces (cf. Morales 2016). With respect to infrastructural access and affordability, Ashaiman is decidedly at a disadvantage (Author 2014). ${ }^{4}$ Direct access to GWCL services is particularly challenging in low-income areas and informal settlements where high capital costs and lack of clear property rights inhibits the extension of piped services (Stoler et al. 2012). Residents in Ashaiman most often pursue a patchwork of approaches, relying on expensive sachet water and a range of other modes of access (Peloso and Morinville 2014). Yet, the price of bottled and sachet water means that these sources can only be relied on for supplemental water, rather than for the range of domestic needs (Interviews; Stoler et al 2012).

Ashaiman's River Gbemi was described by some interviewees as emblematic of poor health in the city; the waters' appearances and odors were experienced as reminders of inadequate infrastructure and urban planning. For example, respondents vividly recalled an incident that occurred two years before, when heavy rainfall swelled the river, unleashing polluted waters and hazardous waste into streets, muddying shoes and households (Interviews, 20 June 2012; 3 July 2012). In Imagining Rivers, Lahiri-Dutt (2000) considers the river a natural phenomenon composed of symbolic meanings; ideas about what a river can or should do are revealing of human hopes and desires. Here, we see vivid connections made between ill-health of the river and of residents nearby who are not adequately protected by infrastructure, whether for daily needs or in times of seasonal flooding.

Water was also discussed as linked to reputation, power and politics among community

\footnotetext{
${ }^{4}$ Authors, 2014 explore other dimensions of water access in Ashaiman beyond price, and suggest conveniences in transactions may also factor in to sachet services and informal water delivery.
} 
members. For one Opinion Leader who also owned a fish pond, the availability of water was crucial both to his livelihood and to his legitimacy as a respected community member. He explained that when he began distributing water from his pond and storage tanks to less fortunate neighbors, the water company (GWCL) cut him off and issued a large bill in reprimand. He felt that the cut-off was inspired by the company's effort to win the people's favor and turn them against him (Interview, 3 July 2012).

On another level, the lack of regularly flowing piped water in Ashaiman was described as an obstruction to moral purity and decried as a factor that inhibited religious devotional practices: "Holiness is cleanliness. Without water our area will not be suitable for God to live in" (Interview, 3 July 2012). This sense was shared by residents from a variety of backgrounds, while it was also clearly linked to Islamic traditions and ritual cleansing. Inadequate water services were also associated with the absence of industry, especially as certain job opportunities such as tie and dye or "wele" require considerable water use (Interview, 29 June 2012).

In these ways, we see that residents understood water to be connected to diverse social and community issues, from livelihoods, to religious devotion, to power and prestige, or to a linked sense that absence of infrastructure is both a result of, and connected to, disconnections of the community from power and politics in Accra more generally. Situations such as this often lead policy makers and academics to call for communitybased water governance institutions in response - to provide a mechanism for greater community control over important local water issues. We now turn to results that speak to the interest in and potential to formalize such community-level water governance institutions in Ashaiman.

\footnotetext{
${ }^{5}$ Cow hide, a chewy snack sold on the street in Ghana.
} 


\section{Participatory Water Governance: Pathways and possibilities}

"What they do is the welfare of each other." (Interview, 11 July 2012)

When asked whether they would participate in water governance institutions, respondents raised capacity, expectations, community interest and potential consequences as key considerations related to their potential involvement. Among other obstacles that would limit their participation in water user groups or similar entities, some highlighted the burden of dedicating time and resources, or difficulties associated with becoming involved in politics. For example, a woman living in the Night Market area explained that she had limited disposable time due to caring for older family members (Interview, 15 June 2012). A 72-year-old man residing in Zongo-Laka indicated that many social groups expected their members to contribute funds, and since he had no funds to offer he would not participate (Interview, 29 June 2012). Another woman, approximately 40 years old and residing in Night Market recounted a negative experience of "politics" and "worries" associated with an organization she had been involved with previously, explaining that she preferred to avoid the stress (Interview, 15 June 2012). Others felt it was the government's responsibility to provide water, thus did not see their own direct participation as necessary: "Everything is under the government so the government has to provide us the water" said a 23-year-old man sitting with his friends at a mobile phone kiosk in Zongo-Laka (Interview, 15 June 2012). He went on to say that if he were to join a community group to discuss water issues in Ashaiman, he would expect reasonable compensation for his time: "...To tell you the truth, if I am going to do that...they have to pay me" (Interview, 15 June 2012).

Not all respondents felt uneasy about participating in water user groups, however. In fact, the idea roused a keen interest in several respondents. Among these, residents invariably emphasized the vitality of water as a motive for their (conjectural) participation - stressing its importance for life and well-being. Below is an excerpt from a discussion with a young woman in her early 20s. She was selling food at a small but lively kiosk.

Interviewer: Do you think that you would want to participate in the meetings?

Respondent: If there are any groups like that, we would have joined, but there are none. 
We don't have it.

I: Let's say imagine there was one. Imagine like today someone came to your community and said: "We are all getting together. We want to talk about the dam or something concerning [water]"

$R$ : We will join.

I: Would you have time?

$R$ : Yes. We would have time.... Because we need it. We need the water.

I: Mhm, okay.

$R$ : Ehee, we need the water so we will have time for it.... So that we can get the water...Because water is life.

(Interview, 29 June 2012)

In line with this sentiment, some stressed that involvement with water issues was a responsibility that one could not afford to ignore. However, the means by which one could be involved and the matter of what would be discussed and acted upon within such a group was largely left up to the respondents to imagine. As such, it should be noted that although several individuals affirmed their interest in participating in water-related groups, there were certainly a variety of motives and differences of opinion in regards to what would constitute such participation. By way of example, a woman living in the Lebanon District of Ashaiman emphasized that it was important to have a place to report water problems:

Interviewer: ...have you heard of any water user associations or water user boards in Ashaiman?

Respondent: No.

I: No organization that just works on water?

$R$ : ... No no no. I don't know any of, of any group or any association that will help if we have a water problem...

I: ...If there was one...let's imagine that. Do you think you would have the time to be involved in something like that?

$R$ : Yes. I will report because I need water. Without water, I can't survive so if I have a problem, even a little problem, I have to report.

I: Mhmm. And do you think other people in your community will be as ready as you to be involved? 
$R:$ They are very, very ready because they need the water to survive. If there is no water, how can you eat? How can you bathe? Even water is [more] important than electricity. (Interview, 27 June 2012)

While our qualitative work confirmed that there were no water-related organizations, there were several other types of community organizations that did exist. Sitting outside an Internet café in Night Market, a young Ewe-speaking ${ }^{6}$ journalist frankly stated: "They [community groups] are there. But basically, what they do is the welfare of each other. Not in terms of development per se" (Interview, 11 July 2012). A similar idea was conveyed two weeks earlier in New Town, speaking with a man and woman on the porch of her home, which doubled as a sewing business. The man, also a taxi driver, said, "I don't think [the clubs] tackle these 'water issues'...It's about support, helping each other out. If somebody is in trouble, they help the person. In Ashaiman, that's how our clubs work" (Interview, 20 June 2012).

In other words, many residents do participate in clubs or groups or organizations that are not specifically water-focused. We suggest that understanding existing modes of participation and engagement is crucial to consider how they might (or might not) be adapted to serve water governance goals, or conversely, how the addition of water-focused governance institutions might fit within the existing community governance landscape. The next section explores a small sample of community associations in Ashaiman, lending a clearer picture of the existing practices and institutions of community-scale governance.

\section{Bricolage: Building on a foundation of existing norms and networks}

"Ete sen?" The community opinion leader asks in Twi. We respond to this greeting that we are well, and express our gratitude for the invitation to this morning's meeting in

\footnotetext{
${ }^{6}$ After Akan and Ga-Dangme, Ewe is the third largest ethnic group in the Greater Accra Metropolitan Area. In the total population of Ghana (including all regions), these groups represent $47.5 \%, 7.4 \%$ and $13.9 \%$ respectively (Ghana Statistical Service, 2012).
} 
Tulako, Ashaiman. The meeting brings together a local Ghanaian group (GHAFUP) and an NGO (People's Dialogue); it is regarding plans to build affordable housing in the community. We take our seats at the back of the room, and are soon called to attention by a group of women wearing vibrant African cloth, standing together singing an opening prayer. The resounding echo that fills the room is deeply moving, despite our inability to understand the local dialect. Much like the rest of Ashaiman, Tulako (a word that locally means "a crowd") is an area characterized by over-crowding and insecure access to water and sanitation facilities. (Fieldnotes, 12 July 2012)

To gain further insights into the clubs, associations and groups in Ashaiman, we attended several meetings, observing them as sites of organized social support. In line with a bricolage approach, we came to understand that although we didn't find any that were focused singularly on water, the meetings offered a window into institutional processes and existing participatory engagement practices in the community. We attended meetings ${ }^{7}$ of several groups to better understand their focus and aims: the Ashaiman Women in Progressive Development (AWPD), Ghana Federation of the Urban Poor (GHAFUP) People's Dialogue (PD), ${ }^{8}$ New Town Friends Club and the Executive Club. A brief characterization of the groups follows.

Meetings were attended by adults in the age range of 25-50 years. Men and women both attended, apart from AWPD which was a women's group. The degree of back and forth between members and openness to sharing positive and negative thoughts as well as adapting the agenda appeared to be fairly strong in all cases, although some differences were evident based on whether residents themselves directed the content and focus of meetings. In the context of one meeting, there were concerns about strong direction from an umbrella organization, leading one participant to contest the strong oversight,

\footnotetext{
${ }^{7}$ All events were regularly scheduled events, either weekly or monthly.

${ }^{8}$ People's Dialogue is a Ghanaian NGO, but it is not local to Ashaiman. Ghana Federation of the Urban Poor and People's Dialogue were partnered in an Ashaiman-based project called "Slum Upgrading" at the time of research.
} 
expressing that they wanted more say in the direction and agenda of the group, noting "everyone should have a taste of leadership."

As we had heard from interviewees earlier, the groups were indeed formed based on ideas of pooling resources, improving living conditions, as well as strengthening social networks and community interaction. It was clear that while there were no water-focused organizations at work during our research, there were a variety of active social and community groups offering pathways for civil society and community engagement. The activities of these groups suggest an interest in creating and participating in community institutions, and refute the possible explanation that water groups are absent due to a lack of trust in neighbors, or a wholesale lack of engagement with participatory decisionmaking or community-based governance (as is at times suggested in the literature, see Auyero and Swistun 2009). In the next section, we look at connections between hydrosocial understandings of water and existing community mobilization, to analyze the implications and opportunities for participatory water governance in Ashaiman.

\section{DISCUSSION}

\section{Revisiting governance histories and possibilities}

In 2009, The Global Water Partnership West Africa released a report entitled "Assessment of Water Governance in Ghana." This was a commissioned report of the Country Water Partnership (CWP-Ghana) to determine the status and role of WUAs in the country. The report states, "existing WUAs sought to promote, primarily, the welfare and socioeconomic interests of their members rather than promoting the rational use of water by their members" (2009, p. viii). In the report, it is suggested that to the extent that WUAs are concerned with broader community welfare, this acts as a hindrance to effective water management; the resulting recommendation is that "roles and operations (should be) specified in unambiguous terms for WUAs in Ghana to promote sustainable management of water resources in the country" (ibid). Implicit in this recommendation is that welfare and socioeconomic interests are not only separable from water use and access, 
but also serve as a critical distraction from the main objective of the WUAs - to properly manage water. In line with the modern water discourse (per Linton 2010), this example illustrates how criteria for "correct" participatory water governance can be defined in ways that explicitly unbundle water from social, political and economic spheres. It also suggests how a siloed or abstract view of water may risk undermining structures or processes of social organization already in place.

In contrast, institutional bricolage offers a means to better understand the "messy" nature of institution-building as part of a healthy and adaptive regime. Scholars working in the Sub-Saharan African region often highlight the importance of unofficial systems of social and economic support, and informal economic activity writ large, particularly in marginalized communities (Oduro 2010; Nino-Zarazua et al. 2012). For instance, it has been observed that arrangements of "informal social protection" are especially instrumental where state welfare services are weak or non-existent, as relationships can help to create a safety net or enhanced ability to cope during difficult or uncertain times (Oduro 2010). Contributing to networks may also be an essential security measure whereby people's contributions serve "to reaffirm or advance their status within their families and communities and their ability to draw on the resources or support of the group in negotiating their own claims to productive resources" (Berry 1993, p. 160). Likewise, institutions emerge from particular histories and relationships, which shape their scope and mandate. In Ashaiman, community-level networks may have inherited mandates and legacies from precolonial and colonial eras, which continue to inform social organization and governance. Diverse modes of traditional social support networks have long operated outside of formal government spaces (Maclean 2002), and remain a characteristic of present day governance in Ghana.

In line with these insights, our analysis accents the need for recognition of informal and extant social arrangements and community governance institutions to recalibrate ideas of participatory water governance going forward. We suggest that it is useful to consider historical roots of existing social networks, as well as contextual understandings that might inform changing possibilities of participatory water governance. Thus, we have aimed to 
provide insights related to existing community governance practices, as well as locally specific understandings of water. Combined, these insights invite a deliberate move away from one-size-fits all water governance institutions that might be promoted by international organizations or governments. The tools and processes to deal with waterrelated concerns are instead understood to be unique in every context, and are influenced significantly by socio-cultural norms and traditions, by the physical setting, as well as specific concerns of the individuals involved (Linton 2010, p. 55). We have sought to give voice to some of these considerations.

Existing community groups often go unrecognized as legitimate institutions by the standards set through development discourse and water policy frameworks, rendering them effectively invisible (Cleaver 2012). However, replacing informal or 'social welfare' institutions with modes more recognizable to outside entities (in this example, water user groups or LWBs) is clearly a justifiable alternative. Using an institutional bricolage framework, we highlight the possibility that multi-purpose groups driven by self-defined and changing priorities can offer lessons for participatory water governance institutions, including the possibility that instead of supplanting existing community entities, we might aim to work with them, or enhance capacity towards pursuing particular goals.

\section{Implications for participatory water governance and policy}

\section{recommendations}

Water governance theorists have increasingly emphasized the need for dynamism to improve adaptive capacity and security in the face of changing conditions (Conca 2006; Pahl-Wostl et al. 2013). Further, evidence suggests that 'fitting' governance regimes within a rigid design of management institutions can reduce the capacity of groups to cope with variability and change (Wilson 2006; Folke et al. 2007). As such, "the optimal 'fit' between institutions and the resources they govern may not be the tightest fit" (Folke et al. 2007, p. 9). Along these lines, there has been increased attention to the possibility that institutions with more flexible agendas and governance structures may be more resilient as compared with those constructed to fix a very specific set of problems. As one example, in 
a study of irrigation co-management in Indonesia, Bruns (2013) observes patterns of episodic mobilization, suggesting that effective social organization may occur at intervals as a response to critical water problems, rather than water issues structuring social organization more generally.

In concert with these discussions, and consistent with the institutional bricolage framework that seeks to explicitly acknowledge that institutions are living, flexible, and evolving (Cleaver 2002; Alexander 2005), we take these insights to challenge some of the common prescriptions related to the need to promote "participatory water governance institutions'. Based on our interviews, it appears that if joining a local water group held the promise of attaining more ready access to water resources, many people would likely show interest and become involved in some capacity. However, existing well-being focused social groups may have the capacity to be adaptive, responding to various community needs as they arise. The institutions we observed had broadly defined, flexible mandates, seemingly with the ability adapt to changing concerns. Similarly, given that community welfare was the central organizing principle for several such groups, this could help to remedy some of the overly technical and 'abstract' water orientations implied by other governance frameworks. As such, we offer that rather than promoting, isolated 'water-only' institutions, practitioners might do better to enable multipurpose welfare and social organizations to deal with water under their remit, to the extent that it emerges as an acute concern in the community. Further, we argue, along with institutional bricolage theorists, that institutions for natural resource management are most effective when "they offer cognitive fit with people's worldviews, providing ontological coherence to understandings of individual and collective action, to people-nature relationships" (Cleaver 2012, p. 48). In this light, it is possible that single-purpose water-focused user groups may not be the most effective or sustainable option for managing complex waterrelated concerns. From Ashaiman residents, we frequently heard "water is life" and similar notions.

For policy makers interested in promoting participatory water governance, our study highlights several interlinked insights. First, it is imperative to gain an appreciation of 
local understandings of water to think through appropriate institutions and practices. Second, the research challenges development agencies and managers to be critically aware of the implicit ways that 'abstract' or 'modern' water views may be imported, contributing to an unnecessary separation of water from other key resources, and even from broader understandings of community well-being. Third, informed by institutional bricolage, we find that a hydrosocial approach that builds on existing social and institutional practices holds promise to be more meaningful, flexible, and adaptive for diverse community contexts. These insights need to be taken seriously, particularly to avoid imposing particular Western views and understandings of what types of institutions are needed and appropriate (cf. Evans 2004). Indeed, the very question of why we expect community members in developing contexts to be involved with the management of their water, when we do not necessarily have similar expectations for Northern counterparts, is a question that deserves consideration.

\section{CONCLUSION}

Where mainstream models of institutional design tend to assume a 'blank slate' upon which new social arrangements can be imported, institutional bricolage theory acknowledges that the past shapes current modes of cooperation and considers how institutions build upon former traditions in light of new needs [ibid, p. 194]. Rather than promoting LWBs and water user groups to respond to community needs, we find insights from these literatures to suggest that institutions can be productively organized around dynamic elements and notions of community well-being. In some senses, this seems all the more compatible with water given its fluidity and movement between diverse facets of everyday life, as relayed by participants in this study, and as conveyed in the literature more broadly (e.g. Neimanis 2013).

Many of our initial questions were guided by a sense that residents can and should be organized to promote their water related needs through formal institutions. What 
respondents told us pushed back against a simple siloed vision of what water is, and what water governance can and should be. These tensions, as surfaced in our research, need to be taken seriously in making decisions about future participatory water governance strategies. Indeed, research design also needs to move forward in ways that are more participatory, allowing the participants to also engage in defining key questions for research, a move that is gaining force with burgeoning literatures on community based research, knowledge co-creation, and knowledge democracy (e.g., Perkins 2014). Aiming to think with, rather than against, existing social networks and community governance mechanisms that we witnessed in our case study site, it is worth exploring how participatory water governance might work to reinvigorate, rather than undermine, existing institutions and civil society fabrics. Doing so is also more consistent with a hydrosocial perspective of water, recognizing that water is part of the socio-political fabric of everyday life and well-being. Taken together, we argue that strengthening and supporting existing social institutions to be able to better address water concerns is a likely to be a more meaningful approach to participatory water governance in this case. The result is certainly meaningful for Ashaiman, and likely elsewhere was well.

\section{ACKNOWLEDGEMENTS}

We would like to acknowledge the support we received from residents and research collaborators in Ghana. In particular, we would like to thank Akosua Darkwah, Innocent Adamadu, Amba Duaa Mensah-Forson, and Elizabeth Dapaah for their guidance and assistance. We also thank our colleagues from the University of British Columbia, who provided insight and expertise that greatly assisted in the development of earlier versions of this paper. We are grateful to Peter Leigh Taylor and two anonymous reviewers whose comments have served to strengthen this article considerably. As sole authors of this paper, we take full responsibility for any shortcomings that remain. 


\section{REFERENCES}

Adank, M., B. Darteh, P. Moriarty, H. Osei-Tutu, D. Assan, and D. van Rooijen. 2011. Towards integrated urban water management in the Greater Accra Metropolitan Area. Accra, Ghana: Switch and RCN Ghana.

Agrawal, A. and C.C. Gibson. 1999. Enchantment and Disenchantment: The Role of Community in Natural Resource Conservation. World Development 27(4): 629649.

Ainuson, K.G. 2009. Ensuring adequate water supply to disadvantaged urban communities in Ghana. Ph.D. Thesis. Clemson University: South Carolina, United States America.

Alexander, E.R. 2005. Institutional Transformation and Planning: From Institutionalization Theory to Institutional Design. Planning Theory 4(3): 209-223.

Auyero, J. and D.A. Swistun. 2009. Flammable: Environmental Suffering in an Argentine Shantytown. New York: Oxford University Press.

Berry, S. 1993. No condition is permanent: The social dynamics of agrarian change in subSaharan Africa. Madison: University of Wisconsin Press.

Brooks, D.B., O.M. Brandes, and S. Gurman. 2009. Making the most of the water we have: The soft path approach to water management. London: Earthscan.

Bruns, B. 2013. Bureaucratic Bricolage and Adaptive Comanagement in Indonesian Irrigation. In The Social Life of Water, ed. J.R. Wagner, pp. 255-277. New York: Berghahn Books.

Budds, J. and L. Hinojosa. 2012. Restructuring and Rescaling Water Governance in Mining Contexts: The Co-Production of Waterscapes in Peru. Water Alternatives 5(1): 119-137.

Cleaver, F. 2002. Reinventing Institutions: Bricolage and the Social Embeddedness of Natural Resource Management. European Journal of Development Research 14(2): 11-30.

Cleaver, F. 2012. Development Through Bricolage: Rethinking Institutions for Natural Resource Management. New York: Routledge.

Cleaver, F. and A. Toner. 2006. The evolution of community water governance in Uchira, Tanzania: The implications for equality of access, sustainability and effectiveness. Natural Resources Forum. 30: 207-218.

Conca, K. 2006. Governing Water: Contentious transnational politics and global institution building. Cambridge: MIT Press.

Cooke, B. and U. Kothari. 2001. Participation: The New Tyranny? New York: Zed Books.

Cornwall, A. 2002. Making spaces, changing places: Situating participation in development. IDS Working Paper No. 173, Institute of Development Studies, University of Sussex, Falmer.

EDGES, AOW Survey. 2012. Water Access and Participatory Governance of households in Informal Settlements in Accra, Ghana and Cape Town, South Africa. www.edges.ubc.ca.

Dapaah, E. K. and L.M. Harris. 2017. Framing community entitlements to water in Accra, Ghana: A complex reality. Geoforum 82: 26-39. 
Denzin, N.K. and Y.S. Lincoln (Eds.). 2011. The SAGE Handbook of Qualitative Research: Fourth Edition. Thousand Oaks: SAGE Publications.

Evans, P. 2004. Development as institutional change: The pitfalls of monocropping and the potentials of deliberation. Studies in Comparative International Development 38(4): 30-52.

Folke, C., L. Pritchard, F. Berkes Jr, J. Colding, U. Svedin. 2007. The Problem of Fit between Ecosystems and Institutions: Ten Years Later. Ecology and Society 12(1): $1-38$.

Ghana Statistical Service. 2012. 2010 Population and Housing Census: Summary Report of Final Results. http://www.statsghana.gov.gh/docfiles/2010phc/Census2010_Summary_report_of _final_results.pdf (accessed 14 February 2014).

Gleick, P.H. 2000. The Changing Water Paradigm: A Look at Twenty-first Century Water Resources Development. International Water Resources Association 25(1): 127138.

Global Water Partnership West Africa. 2009. Assessment of Water Governance in Ghana. Ouagadougou, Burkina Faso: GWP/WA. www.gwpao.org (accessed 24 March 2013).

Harris, L.M., J.A. Goldin, and C. Sneddon. (Eds.). 2013. Contemporary Water Governance in

the Global South: Scarcity, Marketization and Participation. New York: Routledge.

Joy, K. J., S. K. Dik Roth, and M. Zwarteveen. 2014. Re-politicising water governance:

exploring water re-allocations in terms of justice. Local Environment: The International Journal of Justice and Sustainability 19(9): 954-973.

Kaika, M. and E. Swyngedouw. 2000. Fetishizing the modern city: The phantasmagoria of urban technological networks. International Journal of Urban and Regional Research 24(1): 120-138.

Lahiri-Dutt, K. 2000. Imagining Rivers. Economic and Political Weekly 35(27): 2395-2400.

Linton, J. 2010. What is Water: The History of a Modern Abstraction. Vancouver: UBC Press.

Linton, J. 2014. Modern water and its discontents: A history of hydrosocial renewal. WIREs Water 1: 111-120.

MacLean, L.M. 2002. Constructing a Social Safety Net in Africa: An Institutionalist Analysis of Colonial Rule and State Social Policies in Ghana and Côte d'Ivoire. Studies in Comparative International Development 37(3): 64-90.

Mehta, L. 2005. The poetics and politics of water: The naturalization of scarcity in western India. New Delhi: Orient Blackswan.

Mehta, L., M. Leach, P. Newell, I. Scoones, K. Sivaramakrishnan, and S.A. Way. 1999. Exploring Understandings of Institutions and Uncertainty: New Directions in Natural Resource Management (Vol. 372). University of Sussex: Institute of Development Studies.

Morales, M. and L.M. Harris. 2014. Using Subjectivity and Emotion to Reconsider Participatory Natural Resource Management. World Development 64: 703-712.

Morales, M. 2016. My pipes say I am powerful: belonging and class as constructed 
through our sewers. WIREs Water 3(1): 63-73.

Morinville, C. and L. Harris. 2014. Participation, politics, and panaceas: Exploring the possibilities and limits of participatory urban water governance in Accra, Ghana. Ecology and Society 19(3): 36.

Neimanis, A. 2013. Feminist Subjectivity, Watered. Feminist Review 103: 23-41.

Nino-Zarazua, M. et al. 2012. Social Protection in Sub-Saharan Africa: Getting the Politics Right. World Development, 40(1): 163-176.

Oduro, A.D. 2010. Formal and Informal Social Protection In Sub-Saharan Africa. European Report on Development.

Ostrom, E. 1990. Governing the commons: The evolution of institutions for collective action. New York: Cambridge University Press.

Owusu, T.Y. 1999. The Growth of Ashaiman as a Squatter Settlement in the Tema District of Ghana, 1950-1990. The Arab World Geographer 2(3): 234-249.

Pahl-Wostl, C., G. Becker, C. Knieper, and J. Sendzimir. 2013. How Multilevel Societal Learning Processes Facilitate Transformative Change: A Comparative Case Study Analysis on Flood Management. Ecology and Society 18(4): 58.

Peil, M. 1976. African Squatter Settlements: A Comparative Study. Urban Studies 13:155.

Peloso, M. and C. Morinville. 2014. 'Chasing for Water': Everyday practices of water access in peri-urban Ashaiman, Ghana. Water Alternatives 7(1): 121-139.

Perkins, P.E. 2014. International partnerships of women for sustainable watershed governance in times of climate change. In A political ecology of women, water and global environmental change, eds. S. Buechler and A.M. Hanson, pp. 180-140. New York: Routledge.

Perreault, T. 2014. What kind of governance for what kind of equity? Towards a theorization of justice in water governance. Water International 39(2): 233-245.

Rogers, P. and A.W. Hall. 2003. Effective Water Governance. TEC Background Papers No. 7, Global Water Partnership, Technical Committee, Stockholm, Sweden.

Ryan G.R. and H.R. Bernard. 2003. Techniques to Identify Themes. Field Methods. 15(1): 85-109.

Scott, J.C. 1998. Seeing Like a State. New Haven, Yale University Press.

Songsore, J. 2008. Environmental and structural inequalities in Greater Accra. The Journal of the International Institute 16(1): 8-13.

Stoler, J., Weeks, J.R. and Fink, G. 2012. Sachet drinking water in Ghana's Accra-Tema metropolitan area: Past, present, and future. Journal of Water, Sanitation and Hygiene for Development 2(4): 223-240.

Vavrus, F.K. (2003). A Shadow of the Real Thing: Furrow Societies, Water User Associations and Democratic Practices in the Kilimanjaro Region of Tanzania. Journal of African American History. 88(4): 393-412.

Wilson, J.A. 2006. Matching social and ecological systems in complex ocean fisheries. Ecology and Society 11(1): 9. http://www.ecologyandsociety.org/vol11/iss1/art9/ (accessed 15 October 2012). 